\title{
Türkiye'deki Guru Söylemi Modasının Nedenleri*
}

\author{
Dr. Şükrü Özen \\ Başkent Üniversitesi, \\ I.IB.F. Oğretim Üyesi
}

\section{Özet}

Bu çalışmada, Türk yönetim yazını ve uygulamasında son yıllarda yaşanan guru söylemi modasının nedenleri, Abrahamson'ın (1996) yönetim modası oluşturma süreci, Clark ve Salaman'un (1998) nedensel çerçevesi ve Türkiye'ye ö̌gü koşullar dikkate alınarak incelenmeye çalışlmuştır. Guru modasının yapısal, kurumsal ve bircysel nedenleri olduğu belirlenmiştir. Buna göre; öncelikle, kapitalist dünya düzeniyle bütünkşme çabalarının getirdiği yapısal değişim, guru söylemine yönelinmesinin itici gücünü oluşturmaktadır. Daha sonra, yapısal değişimin yarattı̆ı yeni çevresel koşullara uyum zorunluluğu, guru söyleminin arz ve talep yönünü biçimlendirerek, yönetim modası pazarının kurumsallaşmasını sağlamıştır. Diğer yandan, bireylerden (yönetici ve işadamları) kaynaklanan kişiliksel ve sosyopsikolojik etmenler de bu modanın doğmasına ve sürekliliğine katkıda bulunmuştur. Çalışmada son olarak, Türk akademisyenlerinin guru söylemi modası karşısında gösterdikleri tepkiler tartışılmış ve moda sürecine müdahale etmek üzere rollerini yeniden tanımlamaları gerektiği vurgulanmışır.

\section{An Explanation of Guru Fashion in Turkey \\ Abstract}

In this study, the reasons for guru fashion recently prevalent in Turkish management literature and practice are examined by employing Abrahamson's (1996) management-fashion-setting process, Clark and Salaman's (1998) causal framework, and by considering conditions specific to Turkey. As the reasons for the guru fashion, structural, institutional, and individual factors are specificd. The structural change as a consequence of integration with the capitalistic world system is defined as the triggering drive for guru fashion in Turkey. Then, the guru fashion market established during the adaptation process to new environmental conditions emanated from the structural change is seen as anstitutional context where supply and demand sides of the guru fashion are matched. Further, personal and sociopsychological factors are defined as the individual factors which contribute to the emergence and prevalence of guru fashion in Turkey. Finally, various reactions of the Turkish academicians to the prevalent guru fashion are discussed, and a need for redefining their role to intervene in management fashion-setting process is emphasized.

- Bu çalışmanın ilk versiyonu 12-14 Kasım 1998 tarihlerinde Akdeniz. Üniversitesi'nce Antalya'da düzenlenen 6. Ulusal Iş̧letmecilik Kongresi nde sunulmuştur. 


\section{Türkiye'deki Guru Söylemi Modasının Nedenleri}

Sanskritçe'de ruhani lider, pir, üstad anlamına gelen guru sözcügü son yıllarda İ̧letmecilik ve özellikle Yönetim alanında sıkça kullanılmaktadır. Danışman, akademik veya yönetici kökenli bazı kişiler (örneğin, Tom Peters, Gary Hamel, Michael Porter, Michael Hammer, Steven Covey, Kenneth Blanchard, Lee lacocca) birer guru olarak nitelendirilmekte ve ürettikleri fikirler, 1980'li yıllardan bu yana özellikle İngilizce Yönetim yazınnin gündemini belirlemektedir. Öyle ki, Guru Teorisi başığı altında toplanan bu akım, 20. Yüzyılda yönetim düşüncesini etkileyen altı akımdan biri olarak değerlendirilmektedir (Huczynski, 1993). Akademik kökenliler dahil olmak üzere, yönetim alanında zengin bir pratik deneyime sahip olan bu gurular, uygulayıcıların beklentilerine uygun bilgi üretmekte ve bu bilgiyi etkili bir biçimde yaymaktadırlar (Clark, ve Salaman, 1998: 137-161). Buna bağlı olarak da bu akımın ürettiği, değişimi öngören, sorun çözümüne odaklı, iddialı ve hatta sihirli reçeteler, uygulayıcılar tarafindan büyük rağbet görmektedir. Sonuçta, guru söyleminden doğan Toplam Kalite Yönetimi (TKY), Örgüt Kültürü, Öğrenen Örgüt, Yalın Üretim/Yönetim, Yalın Yapı (Delayering), Köktenci Iş Tasanmı (Reengineering), Yetkilendirme (Empowerment) gibi yönetim reçeteleri, son yillarda yönetim modasını (Abrahamson, 1991: 586-612) belirlemekte ve gurular da yönetim modası oluşturma sürecinin (Abrahamson, 1996: 254-285) baş aktörleri olarak karşımıza çkmaktadır. Bu reçetelerin geçerliliğinin şüpheli olduğuna ve hatta (iddia ettiğinin tersine) örgütleri sık sık başarısızlığa götürdüğüne ilişkin uyarılar bile, guruların ve reçetelerinin popülaritesini engellememektedir. Gurular, yüzbin ABD dolara varan ücretler karşılığında dünyanun dört bir yanında konferanslar vermekte ve kitapları dünya çapında milyonlarca adet satmaktadır (örn., Peters ve Waterman'in In Search of Excellence' 5 milyon, Covey'in Seven Habits'i 6 milyon, Hammer ve Champy'nin Reengineering'i 2 milyon adet).

Ülkemizde ise 1990'l yillarda, gurulara ve guru söylemine giderek artan bir ilgi yaşanmaktadır. Özellikle iş çcvreleri tarafından gösterilen bu ilgiye karşılık, son ylllarda mantar gibi çoğalan danışmanlık, eğitim ve yayın kuruluşlarının (i.d.e.a., Management Centre, Arama- Araştırma- Organizasyon- 
Şïkrü Özen • Túrkiye'deki Guru Soylemi Modasııınn Nedenleri • 99

Danışmanlik, YES Consultraining, TMI Türkiye, PDR International, Soysal Danışmanlık, Ekser Danışmanlık, FED Training, Rota Yayıncllk ... gibi) bütünüyle guru söylemini benimsediklerini görmekteyiz. Ünlü guruların (Covey, Drucker... gibi) kitapları Türkçe'ye bir bir çevrilmekte ve yayın hayatına yeni başlayan Capital, Human Resources, Kariyer ve Executive Excellence gibi uygulamaya dönük Türkçe dergiler, guru söyleminin yaygınlaşmasına katkıda bulunmaktadırlar. Ayrica, günlük bir gazetenin pazar eki (Hürriyet/Insan Kaynakları) ve yine günlük bir gazetenin bir köşe yazarı (Milliyet/Ekonomi Kulisi/Meral Tamer), guru söyleminin profesyonel yöneticiler ötesinde, kitlesel bazda popülerleşmesini sağlamaktadırlar. Dahası, son iki yıl içinde, Micheal Porter, Philip Kotler, Steven Covey, Gary Hamel, Peter Senge, Tom Peters, Richard Pascale, Lester Thurow, Edward de Bono, Tony Buzan gibi dünyaca ünlü gurular, sözkonusu danışmanlık, ç̆itim ve yayın kuruluşları tarafından konferanslar vermek üzere ülkemize getirtilmiş, adeta bir guru yağmuru ${ }^{1}$ (Capital, 1998: 172-175) yaşanmıştır.

Ülkemizdeki ilgili akademik çevre ise, iş çevreleri kadar olmasa da guru söylemine belirli bir ilgi duymaktadır. Herşeyden önce, guru söylemine yönelik talep, akademik çevreleri de harekete geçirmiş ve özellikle Istanbul'daki Üniversitelerimizde, guru reçetclerini (TKY gibi) aktaran kısa süreli eğitim programlarında bir artı̧ gözlenmiştir. Öte yandan, akademik kökenli Yönetim yazınunda da, uygulamaya dönük yazındaki kadar olmasa da, guru söyleminin özellikle 1980'lerin ortalarından itibaren etkili olduğu görülmektedir. Örneğin, Furman ve Koralp'in (Furman, ve Koralp, 1997) dört yönetim/organizasyon dergisinde 1972-1996 yılları arasında yayınlanan makaleleri, Bilimsel Yönetim, Insan İlişkileri, Sistem Yaklaşımı ve TKY söylemlerine göre sınfflandırdığı çalışmasında, bu söylemlerin oraniarı, sırasıyla, \%6, \%65, \%23 ve $\% 6$ çıkmaktadır. Bu sonuç, Türk Yönetim yazınına hâlâ Insan Illişkileri yaklaşımı egemen olmasına (Bkz. Üsdiken ve Pasadeos, 1993: 73-93; Özen, 1995: 71-96) rağmen, 1980'lerde yazına giren TKY konusunun tek başına \%6 lik bir pay kapabildiğini göstermcktedir. Bu inceleme, 1972 değil 1985 yılı başlangıৎ alınarak ve sadece TKY değil guru söylemini temsil eden diğer konular da (Örgüt Kültürü, Yetkilendirme gibi) kapsanarak yapılmış olsaydı, guru söyleminin akademik yazınımızdaki etkisi daha çarpıcı bir biçimde ortaya çıabilirdi. Nitekim, 1998 yllında düzenlenen 6. Ulusal Yönetim ve Organizasyon Kongresinde sunulan bildirilerin yaklaşı \%30'una guru söyleminin egemen olduğu görülmektedir. Ayrıca, Kongre Danışma Kurulu Üyesi A. Selami Sargut ile yapılan söyleşi, Kongreye önerilen bildirilerin

1. Grint, "Reengineering History: Social Resonances and Businees Process Reengineering," Organization, 1994, 1(1) 179-201; T. Clark., ve G. Salaman, "The Management Guru as a Organizational Witch-1 Doctor," Organization, 1996, 3(1) 85-107; B. Sandkull, B. "Lean Production: The Myth which Changes the World," The Politics of Management Knowledge (Der.) S.R. Clegg ve C. Palmer, London: Sage, 1996, 69-79; J. Micklethwait, ve A. W(x)ldridge, The Witch Doctors: Making Sense of the Management Gurus. New York Times Books, 1996. 
tümünü incelediğimizde bu oranın daha da yükselebileceğini çağrıştırmaktadır.

Bu izlenim, 12-14 Kasım 1998 tarihlerinde Antalya'da düzenlenen 6. Ulusal Işletmecilik Kongresi'nde, Muhasebe, Finansman, Pazarlama, Insan Kaynakları Yönetimi gibi Işletmeciliğin temel alanları yansıra, TKY gibi guru söyleminden doğmuş bir yönetim anlayışına bir oturum ayrilması ve ayrica kapanıs panelinin de bu konu üzerine olması ile desteklenmektedir. Ancak, yine de, akademik çevrede azınlıkta kalan bir kesimin guru söylemine şüpheyle baktığın söylemek gerekmektedir. Türkiye ve Orta Doğu Amme Idaresi Enstitüsü tarafından Mayıs 1998'de düzenlenen Kamu Yönetiminde Kalite Kongresi, Anadolu Üniversitesi tarafından yine Mayıs 1998'de düzenlenen 6. Ulusal Yönetim ve Organizasyon Kongresi ve en son Akdeniz Üniversitesi'nce düzenlenen 6. Ulusal Işletmecilik Kongresi'ndeki tartışmalardan, böylesi bir izlenim edinmek mümkündür. Azınlığı oluşturan bu akademisyen grubu, guru söylemini bilimdısı, gözboyayıd, yüzeysel, kendi içinde tutarsız ve/veya ideolojik bulmaktadır.

Değindiğimiz tüm bu gelişmeler, ülkemizde yönctim bilgisi üretme ve kullanma alanında önemli değişimler yaşandığın göstermektedir. Herşeyden önce, 1950'lerden bu yana akademisyenlerin elinde tuttuğu, ABD'de üretilen yönetim bilgisini Türkiye'ye aktarma tekeli kırılmış bulunmaktadır*. Akademisyenler tarafindan, aktardıkları bilgiye ilgi göstermemekle ve geleneksel kalmakla yıllardır suçlanan iş çevreleri artık, akademik nitelikli olsun veya olmasın, yönetim bilgisine yoğun bir ilgi göstermekte, ancak bu bilgiyi akademisyenler araclığıyla değil, ya doğrudan kendileri ya da değindiğimiz danışmanlık, eğitim ve yayın kuruluşları aracllı̆ıyla edinmektedirler. Yaşanan böylesi bir gelişmenin sonucunda, 6 . Ulusal İşletmecilik Kongresi'nin kapanş panelinde olduğu gibi, yöneticiler akademisyenlerden bilgi alıcı değil, onlara (örneğin TKY konusunda) bilgi verici konuma gelmişlerdir. Diğer bir deyişle, akademisyenler yaşanan bu gelişmelerin lideri değil, izleyicisi konumunda kalmışlardır. Yukarıda değindiğimiz gibi bu gelişmeler, akademik kökenli Yönetim yazınında da değişime neden olmuştur. Böylelikle, uluslararası Yönetim yazınında son yıllarda yaşanan çeşitlenmelerden bağımsız olarak, 1950'lerden bu yana Insan İlişkileri ve bir ölçüde de Sistem Yaklaşımında direten yönetim yazınımızın, uzun yıllardan sonra ilk defa uluslararası yazındaki yönetim modası ile bütünleştiği görülmektedir

Bu çalışmanın temel amacı, ülkemiz yönetim bilgisi alanında yaşanan bu değişimin nedenlerini araştırmaktır. Ülkemizde yaşanan guru söylemi modasının nedenlerini araştırmak, içinde bulunduğumuz çalışma alanındaki

* Bu saptama, 6. Ulusal Işletmecilik Kongresi'nde "2000"li Yillarda Dönetim ve Örgütsel Davranıs" konulu oturumda Sabancı Üniversitesi nden sayın Behlül Üsdiken tarafından dile getirilmiştir. 
önemli bir gelişmeyi daha iyi anlamak açsından yararh olmasının ötesinde, akademisyenlerimizin büyük ölçüde dışında kaldığı ve sonuç olarak sürüklendiği bu moda karşısında gösterebileceği tavrın oluşmasına katkıda bulunacaktır. Çalışmada öncelikle, guruların ayırdedici özellikleri üzerinde durulacak ve yönetim modası kavramı çerçevesinde guru söyleminin uluslararası yazında moda olmasının nedenleri tartışlacaktır. Daha sonra da guru söyleminin Türkiye'de moda olma sürecinin yapısal, kurumsal ve bireysel nedenleri irdelenecektir. Son olarak, akademisyenlerimizin guru söylemi modası karşısında gösterebilecekleri olası tepkiler ve bu modadan çıkarabileceği dersler tartışlacaktır.

\section{Gurular ve Ayırdedici Özellikleri}

“Kimdir bu gurular?" sorusunu sorduğumuzda uzun bir liste ile karşılaşmaktayız. Capital dergisi, guruları zirvedekiler, vitrindekiler, yıldızı yükselenler biçiminde gruplandırmaktadır (Capital, 1998). Biz aşağıdaki tabloda, sadece bir fikir vermesi açısından, ünlü guruları sıralamayı tercih ediıruz.

\section{Tablo 1: Ünlï Gurular ve Çalışma Alanları}

\begin{tabular}{|l|l||}
\hline Peter Drucker (Yönetim) & Kenneth Blanchard (Motivasyon) \\
Charles Handy (Yönetim) & Edwards Deming (TKY) \\
Jeffrey Pfeffer (Yönetim) & Joseph Juran (TKY) \\
Philip Kotler (Pazarlama) & Masaki Ymai (TKY) \\
Michael Porter (Strateji) & James Champy (Reengineering) \\
Gary Hamel (Strateji) & Michael Hammer (Reengineering) \\
Tom Peters (Örgüt Kültürü,Yenilik) & Alvin Toffler (Gelecek) \\
Edgar H. Schein (Örgüt Kültürü, Liderlik) & John Naisbitt (Gelecek) \\
Richard Pascale (Örgüt Kültürü, Değişim) & Tony Buzan (Yaratıcı Düşünme) \\
Rosabeth Moss Kanter (Değişim Yönetimi) & Edward de Bono (Yaratıct Düşünme) \\
Christ Árgyris (Öğrenen Örgüt) & Lee lacocca (Yöneticilik, Ford, Chrysler) \\
Peter Senge (Ö̈̆renen Örgüt) & Bill Gates (Yöneticilik, Microsoft) \\
Stephen Covey (Liderlik) & Ted Turner (Yöneticilik, CNN) \\
Warren Bennis (Liderlik) & Jack Welch (Yöneticilik, General Electrics) \\
\hline
\end{tabular}


Bu listede bulunan kişiler bizim tarafımızdan değil, yönetim modasın oluşturan kuruluşlar (danışmanlık, eğitim ve yayın kuruluşları) tarafından guru olarak nitelenen kişilerdir. Hatta, bu listede kendisinin guru olarak nitelendirilmesini istemeyenler (Charles Handy, Peter Drucker gibi) vardir ancak, ilgili çevre bu kez gurularn gurusu, yönetim düşünürü gibi nitelendirmeler kullanmaktadır. Görüldüğü gibi, bu gurular arasında Türk akademik çevrelerince uzun zamandır tanınan kişiler olmakla birlikte (Drucker, Schein, Kotler, Handy... gibi) yeni sayllabilecekler isimler de (Senge, Hammer, Hamel, Buzan... gibi) bulunmaktadır. Ayrıca, bu gurular arasında akademik, danışman ve yönetici kökenliler bulunmaktadır ve çalıştıkları alanlar, "genel yönetim"den "yaratıc düşünme" ye kadar uzanan geniş bir yelpaze oluşturmaktadır. Pekâlâ, bu kadar farklı alanlarda çalışan, farklı mesleki kökenlerden gelen bu kişileri "guru" yapan ortak özellikler nelerdir? Diğer bir deyişle "guru"yu, bu alanun geleneksel bilgi üreticisi olan "akademisyen" den ayıran özellikler nelerdir?

Ayırdedici özelliklerini vurgulamak adına, düşünsel (ideel) "guru" ve "akademisyen" tiplemeleri oluşturduğumuzda, üç temel boyutta farklılaşma olduğunu söyleyebiliriz. Aşağıdaki tabloda da görüldüğü gibi, bu boyutlar; (1) bilgiyi üretme biçimi, (2) bilginin niteliği ve (3) bilgiyi yayma biçimi.

\section{Tablo 2: Guruların Ayırdedici Özellikleri}

\begin{tabular}{|c|c|c|}
\hline Boyutlar/Gruplar & Gurular & Akademisyenler \\
\hline Bilgiyi Üretme Biçimi & $\begin{array}{l}\text { Deneyimlere ve sezgilere } \\
\text { dayalı bilgi üretimi }\end{array}$ & $\begin{array}{l}\text { Ampirik arastımalara } \\
\text { dayolt bilgi üretimi }\end{array}$ \\
\hline Bilginin Niteliği & $\begin{array}{l}\text { Dönemin ruhuna ve } \\
\text { yöneticilerin beklentilerine } \\
\text { uygun bilgi }\end{array}$ & $\begin{array}{l}\text { Objektif araştımalara } \\
\text { kuramsal bilgi }\end{array}$ \\
\hline Bilgiyi Yayma Biçimi & $\begin{array}{l}\text { Popüler kitaplar ve } \\
\text { konferanslar yoluyla, } \\
\text { yaygin ve yöneticilere } \\
\text { yönelik yayma biçimi }\end{array}$ & $\begin{array}{l}\text { Akademik kitaplar, } \\
\text { makaleler ve ders yoluyla } \\
\text { ögrenci ve araştırmactlara } \\
\text { yönelik yayma biçimi }\end{array}$ \\
\hline
\end{tabular}

Bilgiyi üretme biçimi açısından gurular ve akademisyenler genel olarak, bilgiyi üretirken kullandıkları metodoloji açısından farklılaşmaktadırlar. Gurular genellikle, deneyimlerine ve sezgilerine dayal olarak bilgi üretirken, 
akademisyenler büyük ölçüde ampirik araşturmalara dayalı olarak bilgi üretmektedirler. Gurular, akademik kökenli de olsa, uzun ylllar süren danışmanlık deneyimleri nedeniyle uygulamayı yakından tanuyan kişilerdir. Danşman kökenli ve hele de yönetici kökenli gurular ise meslekleri gereği uygulamanun içindedirler. Dolayısıyla, ürettikleri bilgi büyük ölçüde edindikleri bu deneyimlere ve bu deneyimlerden doğan sezgilere dayanmaktadir. Uygulama deneyimi görece az olan akademisyenler ise genellikle, akademik yaşamda egemen olan ampirisist metodolojiyi kullanarak, uıgulamayı dışarıdan izlemekte ve daha çok anlamaya yönelik kuramsal bilgi üretimine yönelmektedirler. Iki grup arasındaki bu metodolojik farklılık, aşağıda göreceğimiz gibi, üretilen bilginin niteliği ve yayma biçimi açısından da farklılıklara neden olmaktadır.

Gurular genellikle, dönemin ruhuna ve yöneticilerin/isadamlarının beklentilerine uygun nitelikte bilgi (Clark ve Salaman, 1998); akademisyenler ise, objektif kıstaslara dayalı kuramsal bilgi üretmektedirler. Grint'in (Grint, 1994) belirttiği gibi guruların söylemi zeitgeist'e (dönemin ruhu) uygun bir söylemdir. tleride daha ayrıntılı olarak göreceğimiz gibi, makroekonomik koşullara bağh olarak, Yönetim alanında dönem dönem (karşıtı olan ussal söyleme) baskın olan normatif söylem (Barley ve Kunda, 1992: 363-399) ve politik alanda da egemen neo-liberal ideoloji, dönemin ruhunu oluşturmaktadır. Normatif söylem, Yönetim alanında, işgücü verimliliğini artırmak üzere örgütlerin sistem yönüne değil de, doğrudan sosyal (insan) yönüne odaklanan reçetelerin yoğunlaştı̆̆ı söyleme karşıllı gelmektedir. Diğer yandan son dönemde giderek yaygınlaşan nco-liberal idcoloji ise, girişimcilik, pazarın üstünlüğü, küçülme, yenilikçilik, kökten değişim, bürokratik yapıların yıkılması, esnek, küçük ve yerinden yönetilen birimlerin kurulması gibi eğilimleri yansıtmaktadır. Guruların önerdikleri TKY, Örgüt Kültürü, Yalın Yönetim, Yetkilendirme gibi bir çok yönetim tekniği ve anlayışı, insana odaklı olması açısından normatif söyleme; girişimcilik, müşteri odaklılık, yalınlık, yetkilendirme gibi değerlere dayanması açısından da neo-liberal ideolojiye ve dolayısıyla dönemin ruhuna uygundur. Guruların ürettiği yönetim bilgisi, yöneticilerin değerlerine ve beklentilerine de uygundur (Clark ve Salaman, 1998: 142). Yöneticiler, mesleki nitelikleri gereği, dinamik ve karmaşık çevresel koşulları kontrol etme, liderlik, sorun çözme, pratiklik, eyleme dönüklük ve somutluk gibi eğilimlere sahiptirler. Guruların ürettiği bilgi de, bu beklentileri ve değerleri karşılayacak biçimde, belirsizliği yorumlayan, çözümler üreten, başarı vaadeden somut reçeteler içermektedir.

Akademisyenler ise, aralarında dönemin ruhuna ve yöneticilerin beklentilerine uygun bilgi üretenler olsa bile, genellikle ampirik araştırmalarından elde ettikleri verilere dayalı olarak objektif kuramsal bilgi üretmek eğilimdedirler. Bu bilgide, yöneticilerin beklentilerini karşlayacak unsurlar olmakla birlikte, guruların ürettiği bilgi kadar, belirgin sorunlara 
odaklanmıs somut reçeteler yoktur. Daha çok, betimleyici veya neden-sonu̧ ilişkilerini açılayan, soyutlamaya dayalı teoriler, modeller ve bazı genel ilkeler içermektedir. Akademisyenler, "bilim yapma" eğilimi nedeniyle, herşeyden önce, yöneticilere ve işadamlarına "reçete" üretmek zorunluluğu hissetmezler. Gurularda ise, reçete üretmek bir varolus nedenidir. Öyle ki, Shapiro (Shapiro, 1997: 143), belirsizlikten korkan veya düşünme tembelliği yaşayan yöneticiler oldukça, guruların varolacağını belirtmektedir.

Gurular, ürettikleri bilgiyi yayma biçimleri açısından da akademisyenlerden farklılaşmaktadırlar. Aslında gurular, kitap ve konferans gibi akademisyenlerle aynı iletişim araçların kullanmaktadırlar. Ancak, guruların bu araçlan kullanma biçimleri oldukça farklıdır. Guruların kitapları, ürettikleri bilginin niteliğine uygun olarak genellikle, okuması, anlaşlması ve benimsenmesi kolay, somut, pratik ve yüzeysel bilgiler içermektedir (Conrad, 1985: 426-429; Freeman, 1985: 345-350). Ayrica, gurular konferanslarinda, ilgi uyandirıa anektod ve esprilerle bezenmiş, konuşma yeteneğine ve iknaya dayalı bir iletişim biçimi kullanmaktadırlar (Clark ve Salaman, 1998: 143). Huczynski'ye (Huczynski, 1993) göre, gurular genellikle, Lewin'in ü̧ aşamalı değişim modelini izleyen ikna edici bir iletişim biçimi kullanmaktadırlar. Bu modelde gurular öncelikle, yöneticilerin mevcut inançlarına ve uygulamalarına meydan okumakta (çözme aşaması), ardından değişim olmadığ takdirde batma tehlikesini ve kurtuluşun kendi çözümlerinde olduğunu vurgulamakta (değişme aşaması) ve son olarak, kendi yaklaşımlarını çözüm olarak yöneticilere benimsetmeye çalışmaktadırlar (kalıplama aşaması).

Akademisyenler ise, ürettikleri ampirik ve kuramsal bilgiye koşut olarak, genellikle, analitik, kuramsal, betimleyici veya genel ilkeler içeren kitaplar yayınlamaktadırlar. Bu kitaplar, guruların kitaplarıyla karşılaştırıldığında, yöneticiler tarafından okunması ve anlaşılması daha zor kitaplardır. Diğer yandan, varolan sorunlara somut çözüm önerileri içermek yerine betimleyici ve genel ilkeleri koyması nedeniyle, yöneticilerin o denli ilgisini çekmemektedir.

Gurular ve akademisyenler arasındaki bu farkllıklara zemin oluşturan koşulsal etmen, yönetim modası pazarıdır. Curular, akademisyenlerden farklı olarak bu pazarın odağında ycr almaktadırlar. Bu nedenle guru söyleminin uluslararası alanda moda olmasının nedenlerini, bu pazarın iç dinamiklerinde aramak gerekmektedir.

\section{Guru Söylemi Modasının Uluslararası Dinamikleri}

Gurular, yönetim bilgisi üreten diğer gruplar gibi (danı̧̧manlık ve yayın kuruluşları, yönetim okullan, akademisyenler, işadamlan, yöneticiler), yönetim modası oluşturma sürecinin temel belirleyicileridir. Bu nedenle guru modasın, yönetim modası olgusu içinde değerlendirmek gerekmektedir. Abrahamson 
(Abrahamson, 1996: 257) yönetim modasım, "moda belirleyicilerinin, belirli yönetim tekniklerinin ussal gelişme sağlayacağına ilişkin yaydıkları geçici ortak inançlar" olarak tanımlamaktadır. Yönetim modası, yönetim bilgisi üreten ve yayan kurum ve kişilerin (yönetim modast belirleyicileri) katıldığı bir yönetim modası oluşturma sürecinin çıtısıdır (Abrahamson, 1991). Yönetim modast oluşturma süreci ise, moda belirleyicilerinin, ussal yönetim gelişmesi sağlayacak tekniklere ilişkin hem kendilerinin, hem de moda kullanucilarınn ortak inançların biçimlendirdikleri bir süreç olarak tanumlanmaktadır (Abrahamson, 1996: 257). Bu süreç içinde, örgütlerin başarısında çlkan olan ilgili çevrelerin (örneğin, hissedarlar), yöneticilerden ussal ve gelişmeden yana eylemler beklemeleri, yöneticileri, ussal gelişme sağlayacağına inandıkları yeni yönetim tekniklerine yöneltir. Yönetim modası belirleyicileri ise, kendi içlerinde rekabet halinde, kullanucı tercihlerini bir yandan izlerler, bir yandan da çeşitli yönetim tekniklerine ilişkin oluşturdukları söılemlerle bu tercihleri biçimlendirirler. Bu izleme süreci sonucunda moda belirleyicileri, tercihleri karşlayabileceğine inandıkları bir çok yönetim tekniği yaratırlar ve bunların içinden talebi en iyi biçimde doyuracağına inandıkları yönetim tekniklerini seçerler. Daha sonra, bu yönetim tekniklerine ilişkin söylemi tasarlarlar ve çeşitli yayma yöntemleri kullanarak bu teknikleri kullanicilara sunarlar (Abrahamson, 1996: 263-270).

Yönetim söyleminde zaman içinde yaşanan ve çan eğrisi biçiminde bir seyir izleyen moda dalgalanmaları çeşitli biçimlerde açklanmaktadır. Örneğin, Barley ve Kunda (Barley ve Kunda, 1992) bunun, büyük ölçüde makroekonomik dalgalanmalarla ilintili olduğunu ileri sürmektedir. Buna göre, makroekonomik koşullarda genişleme ve canlılı̆̆ın yaşandığı dönemlerde, kârlılık büyük ölçüde sermaye yatırımına ve otomasyona bağımlı olduğu için, işgücü verimliliğini yüksel tmek üzere, örgütsel yapların ve teknolojilerin (yani, örgütlerin "teknik" yanı) etkin kullanımına yönelik yönetim tekniklerine talep artmakta ve bu talep Yönetim alanında bir ussal söylem modası doğurmaktadır. Daralma ve durgunluk dönemlerinde ise, sermayenin hem arzı hem de geri dönüş oran düştüğünden, yöneticiler bir üretim faktörü olarak işgücüne yönelmekte (yani, örgütlerin "sosyal" yönü) ve isgücü verimliliğini yükseltmek üzere insan ilişkilerine dönük yönetim tekniklerine rağbet etmektedirler. Bu da sonuç olarak, yönetim alanında normatif söylem modasına neden olmaktadır.

Abrahamson (Abrahamson, 1997: 491-533) sarkaç tezi olarak adlandırdığı bu tezi, görgül verilere dayalı olarak test etmiş ve 1875-1992 yılları arasında Ingilizce Yönetim yazınında egemen olan Refah Yönetimi (1872-1894), Bilimsel Yönetim (1894-1921), Insan İlişkileri (1921-1944), Sistem Ussallı̆ı (1944-1971) ve Örgüt Kültürü/Kalite (1971 den günümüze) söylemlerinin, çeşitli geçişmelerle birlikte, makroekonomik düşüş ve yükselişlere bağh olarak popülarite kazandığını ve gözden düştüğünü kanıtlamıştır. Barley ve Kunda'nın (Barley ve 
Kunda, 1992) görüşünü destekler biçimde, normatif söylemler (Refah Yönetimi, Insan llişkileri ve Örgüt Kültürü/Kalite) düşüş dönemlerinde; ussal söylem ise (Bilimsel Yönetim ve Sistem Ussallığı) yükseliş dönemlerinde daha popüler hale gelmektedir.

Gurular, 1971 'den günümüze dek popülerliğini sürdüren Örgüt Kültürü/Kalite normatif söyleminin oluşmasında, en önemli moda belirleyicileri olarak karşımıza çıkmaktadır. Guruların neden içinde bulunduğumuz dönemde öne çıktğın anlayabilmek için, bu dönemi biçimleyen sosyockonomik ve kültürel değişimleri, yöneticilerin tercihlerini ve guruların bu tercihlere nasıl karşllık verdiğini anlamamı gerekmektedir. Guruların ve guru teorisinin popüler olmasının nedenlerine ilişkin çalışmalan inceleyen Clark ve Salama (Clark ve Salaman 1998: 144-146), ü̧̧ temel nedeninin öne çıktığın belirtmektedir; sosyoekonomik/ kültürel nedenler, yöneticilik mesleğinden ve gurulardan kaynaklanan nedenler.

Buna göre, guru söylemi modasının temel nedenlerin biri, guruların, makroekonomik ve politik gelişmeler sonucunda Yönetim alanında ve politik alanda egemen hale gelen söylemlere (dönemin ruhuna) ve kültürel değerlere uyumlu bir söylem geliştirmeleridir. Makroekonomik koşulların 1970'li yıllarda olumsuz yönde seyretmesiyle birlikte (petrol krizi, uluslararası rekabetin artması, kâr oranlarının düşmesi gibi), verimliliği artırmak üzere, doğrudan işgücüne yönelinmiş ve bu da Yönetim yazınında normatif söylemin doğmasına neden olmuştur. Işte guruları 1970'lerden bu yana popüler kılan etmen, kendi söylemleri ile, Yönctim yazınında o dönemde egemen olan söylemin (normatif) örtüşmesidir. Guruları popüler kılan bir diğer koşulsal etmen ise, özellikle 1980 'li ylllarda $\mathrm{ABD}^{\prime}$ de ve uluslararası alanda popüler hale gelen neo-liberal politik söylemi arkalarına almalarıdır. Böylelikle gurular, hem politik alanda hem de Yönetim alanunda egemen olan söylemlere uyum sağlayarak popüler hale gelmişlerdir. Öte yandan, guru söylemi, iyimserlik, basitlik, bireycilik, girişimcilik, liderlik gibi Amerikan rüyasını oluşturan toplumsal değerlere de büyük ölçüde uyum göstermektedir. Aynı zamanda, guru söylemi, Japon tehdidine karşllık bu değerlere dönülmesi gerektiğini vurgulayarak, toplumun kendine güven hissini okşamaktadır.

Guru söylemini popüler kılan bir diğer neden ise, guruların, söylemlerini ve bilgiyi sunuş biçimlerini, yöneticilerin beklentilerine ve değerlerine başarıyla uyumlamalarıdır. Yukanda belirttiğimiz gibi, gurular ürettikleri bilgi ile, yöneticilerin değerlerine ve beklentilerine odaklanmakta, onlara belirsizliği yorumlayan ve başarı vaadeden reçeteler sunmaktadırlar. Ayrıca, popüler kitaplar ve ikna edici iletişim teknikleriyle donatılmış konferanslar aracılığıyla, ürettikleri bilgiyi etkili bir biçimde yaymaktadırlar.

Clark ve Salaman bu açıklama biçimlerine ek olarak, guruların 
"başarısın", üst düzey yöneticilere kahraman, dönüştürücü lider kimliği sunmalarına bağlamaktadır. Dolayısıyla, gurular sadece örgütsel olgulan değil, yöneticilerin kendisini de kurgulayarak ve onlara çekici bir kimlik sunarak yöneticilerin ilgilerini çekmektedirler. Öte yandan, Abrahamson'ın (Abrahamson, 1996: 272) belirttiği gibi, yöneticiler sırf moda akımun dışında kalmama, prestij kazanma ve yenilikleri takip ediyormuş izlenimi yaratma gibi nedenlerle, guru modasınin popülaritesine destek veriyor olabilirler.

Sonuç olarak guruların, bir yandan egemen politik ve yönetim söylemlerine dayanarak, diğer yandan da yönetim modası kullanucılarınun tercihlerini, diğer moda belirleyicilerine göre daha iyi okurarak ve buna uygun yönetim teknikleri önererek, yönetim modası pazarında egemen oldukların söyleyebiliriz.

\section{Türkiye'deki Guru Modasının Nedenleri}

Türkiye'de yaşanan guru ve guru söylemi modasınun nedenlerini tartı̧̧madan önce, ülkemizi, uluslararası yönetim modasının oluştuğu ülkelerden ayıran özellikler üzerinde durmak gerekmektedir. Herşeyden önce Türkiye, yönetim modası oluşturan bir ülke değil, diğer ülkelerde oluşan modayı ithal eden bir ülkedir. Dolayısıyla ülkemizde yaşanan bir yönetim modası oluşturma süreci değil, yönetim modası ithal etme sürecidir. Türkiye'de de Abrahamson'ın tanımladığı şekilde bir yönctim modası pazarı vardır ancak, bu pazarda moda belirleyicileri ve kullanıcları değil, moda ithalaţ̧ılan ve öykünmecileri vardır. Moda ithalatçılan, yabancı yönctim tekniklerine öykünen yönetici ve işadamlarının isteklerine uygun yönetim tekniklerini ithal ederler ve yine ithal ettikleri söylem ve yayma biçimleriyle bu teknikleri onlara sunarlar. Türkiye'nin, yönetim modası oluşturma sürecinin merkezinde değil kenarında olması, ileride değineceğimiz gibi, guru modasını açıklamada özellikle kültürel ve sosyopsikolojik etmenleri öne çlkartmaktadır. Bu temel farklılk, Abrahamson'ın yukarıda aktardığımız ve gerisinde moda üreticilerinin ve kullanıcılarının büyük ölçede rasyonel davrandıkları varsayımı bulunan yönetim modası sürecinin, Türkiye için pck geçerli olamayacağı şüphesini uyandırmaktadır. Aşağıda ayrıntılı bir biçimde tartşacağımız gibi, guru söyleminin gerisinde, değişen çevresel koşullara uyum sağlayarak yaşamın sürdürme gibi rasyonel nedenler olabileceği gibi, azgelişmişlik sendromundan, prestij kazanmaktan, "modernmiş gibi" görünmekten ve kimlik edinme uğraşından kaynaklanan irrasyonel nedenler de bulunmaktadır.

Türkiye'nin uluslararası yönetim modası pazarının dışında olması diğer yandan, Türk Yönetim yazınının, uluslararası pazarda yıllar itibariyle yaşanan moda dalgalanmalarından farklı bir seyir izlemesi sonucunu doğurmuştur. Yukarıda sarkaç tezini anlatırken belirttiğimiz gibi, uluslararası yönetim yazını 
makroekonomik dalgalanmalara bağlı olarak normatif ve ussal söylemler arasında gidip gelmiştir. Ancak Türkiye, ilk kez ABD Yönetim yazını ile 1950'li yıllarda etkileşim içine girmiş ve o yıllarda bu yazında moda olan söylemi (Insan llişkileri) ithal etmiştir. Erken dönemde benimsenen bu yaklaşım, Türk yönetim yazınına damgasını vurmuş (Üsdiken ve Pasadeos, 1993; Üsdiken, Selekler, Cetin, 1998: 57-88) ve bu damga, yukarıda değindiğimiz gibi, günümüze dek sürmüştür (Bkz. Furman ve Koralp, 1997). Türk Yönetim yazınındaki bu tekdüzelik, erken dönem etkisinin belirleyiciliğinin yanında, yönetim bilgisi üreten akademik kurumların, farklılı̆̆ özendirmeyen ve Türkiye'deki yönetim uygulamalarına ilgi göstermeyen bir anlayışa sahip olmasıyla da açıklanmaktadır (Üsdiken ve Pasadeos, 1993). Öte yandan, bu Insan Ilişkileri yaklaşımına sarılmamız, toplumsal kültürümüzde dişillik, kolektivizm gibi değerlerin egemen olmasına (Hofstede, 1984), yönetim anlayışımızda insan ilişkilerine dönüklügün belirgin olmasına (Özen, 1996) ve bu yaklaşımın akademisyenlerimizin mensup olduğu orta sınıfın demokratiklik, insancillık gibi değerlerini okşamasına bağlanabłlir.

Ancak, son yıllarda farklı bir olgu yaşanmaktadır. Türk Yönetim yazınndaki tekdüzeliği tehdit eden bu değişim, guru söyleminin gittikçe popüler hale gelmesidir. Türk Yönetim yazın uzun yıllardan sonra belki de ilk kez, uluslararası Yönetim yazınındaki güncel bir modaya ayak uydurmuş görünmektedir. Daha da önemlisi, Türkiye'de belki de ilk kez, uygulayıclar (yöneticiler ve işadamları) uluslararası alanda üretilen yönetim bilgisine bu denli fazla ilgi göstermektedirler. Türkiye'de neden böyle bir değişim yaşanmıştır?

$\mathrm{Bu}$ değişimi, aşağıdaki kavramsal çerçeveyi temel alarak açılamaya çalışacağız. Sosyal düşüncelerin popülerleşmesinde belirli bir sürecin sözkonusu olduğu belirtilmcktedir (Alvarez, 1996: 83-84). Bu sürece göre, öncelikle, eski düşünceleri gayri meşrulaştıran ve yeni düşüncelerin yolunu açan, ekonomik, toplumsal ve politik alanda harekete geçirici gelişmelcrin olması gerekmektedir. Bu gelişmeler, yapısal etmenler olarak adlandırılacaktır. Ikinci olarak, bu yapısal değişimlerle etkileşim içinde, yönetim bilgisinin üretildiği, aktarıldığı ve tüketildiği kurumsal bir bağlamın olması gerekmcktedir. Kurumsal etmenler olarak adlandıracağımız bu grup, yönetim modası pazarını oluşturan örgütlerin içsel koşullarını ve karşıltk $h_{1}$ etkileşimlerini içermektedir. Son olarak, bilginin yayılmasında ve popülerleşmesinde rol alan örgütlerdeki bireylerin davranı̧ları ve etkileşimleri etkili olmaktadır. Bireysel etmenler olarak adlandıracağımız bu grup ise, sözkonusu bireylerin kişiliksel ve sosyopsikolojik eğilimlerini içermektedir. 


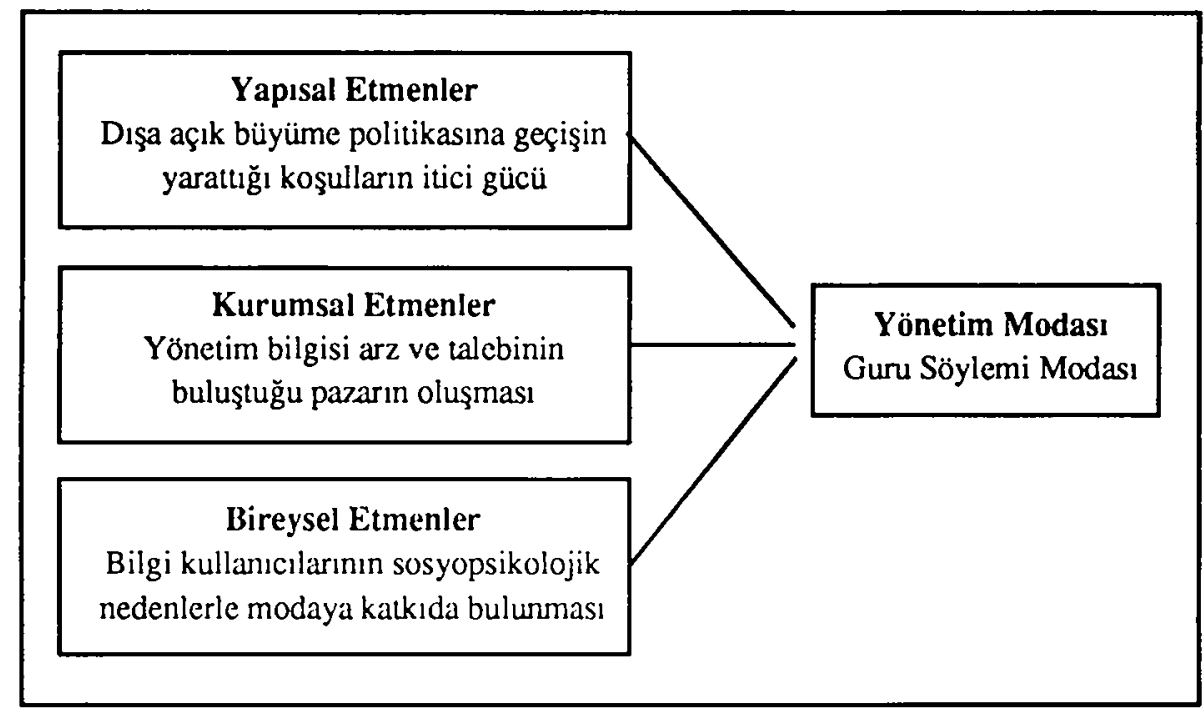

Şekil: Türkiye'deki Guru Söylemi Modasını Açılayıcı Kavramsal Çerçeve

Böylesi bir kavramsal çerçeve kullanmanın en önemli yararı, yazında birbirinden bağımsız ve hatta rakipmiş gibi gösterilen etmenlerin, aralarında öncelik ilişkisi kurarak bütünleştirilmesidir. Ramsay'ın (Ramsay, 1996: 155-172) belirttiği gibi, yönetim modasın anlayabilmek için, sadece bir grup etmen üzerinde yoğunlaşmak yerine, tüm etmen grupların ve bunlar arasındaki ilişkileri bütünleşik bir çerçeve içinde değerlendirmek gerekmektedir. Türkiye'deki guru söylemi modasın açıklayabilmek için öncelikle, harekete geçirici yapısal etmenleri, daha sonra ateşlenen bu değişimi kurumsallaştıran kurumsal etmenleri ve en sonunda da bu değişimi sürekli kılan bireysel etmenleri incelemek gerekmektedir.

\section{Yapısal Etmenler}

Türkiye'de guru söyleminin popülerleşmesi ile sonuçlanan sürecin harekete geçirici yapısal unsuru, 1980'lerin başında yaşanan ithal ikamesi politikasından dışa açık büyüme politikasına geçiştir. Döviz ve dış borç krizi ile tıkanan ithal ikamesi politikası 24 Ocak kararları ile terkedilmiş, yerli sermayeyi koruyucu gümrük duvarları indirilmiş, ithalat sınırlamaları yumuşatılmıs, ihracat özendirilmiş ve yabancı sermaye yatırımlan teşvik edilmiştir. Bu radikal değişim, 1995'de Avrupa Gümrük Birliği anlaşması ile pekiştirilmiş ve Türkiye ekonomisi kapitalist dünya düzeninin bir parçası haline getirilmiştir. 
Daha önceleri, gümrük duvarlannn koruması altında, rekabetin düşük olduğu iç pazara yönelik, üretim odaklı çalışan yerli sermaye için bu makrockonomik değişim, "yepyeni çevresel koşullar" anlamına gelmekteydi. Artık daha rekabetçi, değişken ve karmaşık bir çevre dokusu sözkonusu idi. Nitekim, yeni ekonomik düzenin gerektirdiği girişimci tipi, bizzat Turgut Özal tarafından, "rekabete açı, ayakları üzerinde durabilen, firsatları değerlendirebilen, dıs pazarlara dönük kişi" olarak tanımlanmakta idi. Ancak, o yıllara dek rekabetçi, pazara odaklanmış bir yönetim anlayışı geliştirme veya böylesi bir anlayışı ithal etme ihtiyacı hissetmemiş yerel sermaye için bu değişim, "şimdi ne yapacağız?" türünden bir belirsizliği de beraberinde getirmiştir. Sonuç olarak yaşamın sürdürmek zorunda olan yerel sermaye bu belirsizlikle, aşağıda daha ayrıntılı bir biçimde açıklayacağımız süres içinde, yurtdışından yönetim bilgisi ithal etme yoluna giderek başetmeye çalışmıştır. Ithal ettiği yönetim bilgisi ise, 1980'li yıllarda uluslararası Yönetim yazınında moda olan ve guru söyleminin egemen olduğu normatif söyleme ait yönetim bilgisi idi.

Dolayısıyla, bugün Türkiye'de moda olan guru söyleminin ateşleyici gücünün, yerel sermayenin $1980^{\circ} \mathrm{li}$ yıllarda değişen ekonomik koşullara uyum sağlama çabası olduğunu söyleycbiliriz. Bu çaba sonucunda, aşağıda belirteceğimiz kurumsal bağlam oluşmuş ve sonuç olarak Türk Yönetim yazını tarihinde ikinci kez, uluslararası yönetim modasın eşzamanlı olarak yaşamıştır. Daha önce belirtildiği gibi, Türk Yönetim yazınının, uluslararası yönetim modası ile ilk buluşması 1950'li ylllara rastlamaktaydı. Ilginçtir ki, bu yıllarda da (pek başarılı olmasa da) 1980'li yıllara benzer olarak, dünya kapitalist düzeni ile bütünleşme girişimi yaşanmıştır. Bu koşutluk, ckonomik alanda dişa açllma ile, yönetim alanında dışa açılma arasında bir ilişki olduğunu akla getirmektedir. Bunun başlıca nedeni, kapitalist dünya düzeniyle benzer ekonomik koşullara sahip olduğunda, yerel serma yenin o koşullarda geçerli olduğunu "düşündüğü" benzer tekniklere ilgi göstermesi olabilir. Sonuç olarak, dışa açılma döneminde uluslararası yazında hangi yönetim söylemi moda ise o ithal edilmektedir; 1950'lerde İnsan Ilişkileri söylemi ise, 1980'lerde de Örgüt Kültürü/Kalite söylemi.

Dolayısıyla, Barley ve Kunda'nın sarką̧ modelinde olduğu gibi, Türkiye'deki yönetim modası dalgalanmalan ekonomik koşullardaki değişimlerle açlklanabilir ancak, Türkiye için farklı olan, bu ckonomik koşullann gerisinde dünya kapitalist düzeniyle bütünleşme veya içe kapanmaya ilişkin, temelde politik nitelikli tercihlerin egemen olmasıdır. Sonuç olarak, "Türkiye'deki yönetim modası değişimleri, kapitalist dünya düzenine açlma ve içe kapanma dönemleriyle ilintilidï" biçiminde bir öneri, görgül verilerle test edilmeye değer görülmektedir. 


\section{Kurumsal Etmenler}

Çevresel koşullardaki değişimin itici gücü ile, kendilerine özgü rekabetçi yönetim teknikleri geliştiremeyen ve bu konuda yerel akademik çevrelerden yeterli katkıyı sağlayamayan iş çevrelerinin, yurtdışından yönetim teknikleri ithaline yöneldiklerini yukarıda belirtmiştik. Örneğin, Koç ve Sabancı Holdingler, yabancı danışmanlık şirketleri yardımıyla yönetim sistemlerini yeniden düzenlemişler, eğitim birinlerinin etkinliklerini genişletmiş ve yoğunlaştırmışlardır. A yrıca, yabancı şirketlerle ortaklıklar sonucunda da, yeni yönetim tekniklerini uygulama şansı bulabilmişlerdir. Buna örnek olarak, Sabano Holding'in TOYOTA ile ortaklı̆̆ sonucunda TKY ile tanı̧̧ması gösterilebilir. Büyük şirketlerdeki bu değişim, daha sonra onları izleyen şirketleri de harekete geçirmiş ve onlar da TKY eksenli olmak üzere yeni yönetim teknikierine ilgi göstermeye başlamışlardır. Bu gelişmede elbette ki, uluslararası pazarlar yanında ulusal pazarda da tüketicilerin kalite konusunda daha duyarlı hale gelmesi, tükcticinin korunması konusunda yasal ve kurumsal gelişmelerin yaşanması, TSE belgeli ürünlerin tercih edilir olması ve daha sonra ISO 9000/ISO 9001 belgesinin "kaliteli şirket" imajı oluşturmada ctkili olması da pay sahibidir. Ayrıca, çৎşitli şirketlerimizin, TUSiAD-KalDer Ulusal Kalite Ödülünü ve Avrupa Kalite Büyük Ödülünü alması da, bu modanın yaygınlaşmasına katkıda bulunmuştur.

Yönctim modası sürecinin talep yanındaki bu gelişmelere koşut olarak, arz yanında da kurumsal bazı gelişmeler yaşanmıştır. Yeni yönctim tekniklerine talebin artması, daha önce belirttiğimiz gibi bir dizi yayın, cğitim ve danışmanlık kurumunun bu pazara girmesine neden olmuştur; bizzat Kos Holding tarafından kurulan i.d.e.a., TUSIAD önderliğinde kurulmuş bir sivil toplum kuruluşu olarak KalDer ve Management Centre, Arama-Araştırma-Organizasyon-Danışmanlık, YES Consultraining, TMI Türkiye, PDR International, Soysal Danışmanlık, Ekser Danışmanlık, FED Training, Rota Yayıncilı ...gibi. Yatırım maliyetlerinin oldukça düşük olması nedeniyle bu pazara giren şirket sayısı kısa zamanda hızla artmıştır. Geçen yılın rakamlarına göre yaklaşık 600 danışmanlık kuruluşu bulunmakta ve günümüzde bu sayının 1000 dolaylarında olduğu varsayılmaktadır (Human Resources, 1997a: 24-27). Kuruluş sayısının kısa zamanda bu denli artması ve sunulan ürünün de soyut nitclikte olması, bu sektörde bulunan kuruluşları, bir dernck altında toplanma (Yönetim Damısmanlan Derneği gibi) ve sektörün özdenetimini sağlayacak norm ve standartları belirleme biçiminde bir "kurumsallaşmaya" yöneltmiştir (Bkz. Human Resources, 1997a: 24-27; Capital 1997: 130-131). Diğer yandan, yine guru söyleminin egemen olduğu, Capital, Human Resources, Kariyer, Executive Excellence gibi uygulamaya dönük dergiler de Türk yönetim yazınına bu ylllarda girmişlerdir. Son olarak, çৎ̧̧itli akademik kurumlar da kısa süreli programlarla bu kervana katılmışlardır. 
Kurumsal yapısı böylece oluşan Türk yönetim modası pazarınun en önemli özelliği, daha önce de belirttiğimiz gibi, arz tarafın oluşturan kurumların, yurtdışındaki danışmanlık, yayın ve eğitim kurumlarınun bazen resmi, bazen de fiili acentası olmalarıdır. Dolayısıyla, moda oluşturma süreci dışında olan Türkiye'de, yönetim tekniklerini arz eden kurumlar, Abrahamson'ın belirttiği gibi rasyonel bir biçimde kullana tercihlerini izleyip ona uygun yönetim teknikleri üretmemekte, sadece talep edilen yurtdışı reçeteleri ithal edip, yine ithal edilmiş yöntemlerle kullanucya sunmaktadırlar. Ayrıca, bu kuruluşların, talebi biçimlendirme ve somut anlamda belirli tekniklerin ussal gelişme sağlayacağı yönünde kullanıcıyı yönlendirmesi pek sözkonusu değildir. Çünkü, moda tekniklere olan talep, dışa açlmanun itici gücü ve yukanda saydığımız diğer nedenlerle zaten oluşmuş bulunmaktadır. Dolayısıyla, arz kuruluşlarına sadece, birbirleriyle rekabet ederek bu teknikleri ithal etmek ve kullanıcılara sunmak düşmektedir.

Yönetim danşmanlığı scktörü, düşük yatırım maliyetlerinden ötürü girişin kolay ve ürünün soyut nitelikli olduğu bir sektördür. Bu koşullar, yönetim bilgisine ihtiyaç duyan müşterinin, kalitesinden pek emin olmadiğı hizmetler sunan çok sayıda danışmanlık şirketi arasında bir seçim yapma sorunu yaratır. Bu nedenle, yönetim danışmanlığı şirketleri birbirlerile rekabet ederken, çeşitli yöntemlerle (örn; ikna, etkili iletişim, öykü anlatma gibi) müşteri gözünde "iyi imaj yaratmaya" yönelirler (Clark, ve Salaman, 1996b: 166-184). Işte, Türkiye'de son yıllarda yaşanan guru akını, böylesi bir imaj yaratma uğraşının sonucudur. Danı̧manlık, eğitim ve yayın kuruluşları, guru söyleminin bir tür tutundurma yöntemi olan guru seminer ve konferanslarını, bu söylemin bir kurumu olarak ithal etmişlerdir. Guru getirtme olgusu, hem aşağıda belirteceğimiz nedenlerle oluşmuş bir talebi karşılayan kârlı bir pazar olmuş, hem de bu kuruluşların temel ürünlerine olan talebi rekabetçi bir biçimde artırma işlevi görmüştür. Dolayısıyla, kısa zamanda "kim kimi getirtecek bakalım?" olgusu yaşanmıştır. Sonuç olarak yönetim modası içinden yeni bir moda türemiştir; guru getirtme ve izleme modası.

\section{Bireysel Etmenler}

Yönetici ve işadamlarımızın genelde guru söylemine ve özelde guru seminerlerine duyduğu ilgiye, kültürel ve sosyopsikolojik etmenler de katkıda bulunmaktadır. Herşeyden önce, ekonomik koşulların değişmesiyle birlikte uyum sürecine giren yönetici ve işadamlarımızın, ulusal yönetim teknikleri üretmek yerine gelişmiş ülkelere yönelmeleri ve onları bir "model" olarak almaları, ülkemizin modernleşme süreci ile edindiği bir gelenektir. Nitekim, yöneticilerimiz ve işadamlarımız üzerinde yapılan bir araştırmada (Human Resources, 1997b: 32-33), bu kesimin bütünüyle “Dünya'da geçerli ise Türkiye'de de 
geçerlidir" tezini savunduklann görmekteiz. Bu kesim aynca, toplumsal kültürümüzün, yönetim tarzımızı nasıl etkilediğini bilmediklerini, Dünya'da uygulanan yönetim tarzlarının Türkiye'de de uygulanabileceğini veya en azından, "nitelǐğinden pek emin olmadıklan bir senteze" ulaşlabileceğini belirtmektedirler. Bu ifadeler, "kendini tanumayı" önemsememenin ve doğrudan dışardaki bir "modele" öykünmenin tipik ifadesidir. Diğer yandan, bu öykünmecilik, gelişmiş ülkelerdeki çözümleri olduğu gibi kabullenme biçiminde karşımıza çıkan bir az gelişmişlik sendromu olarak da nitelendirilebilir.

Guru söyleminin Türkiye'de tutmasınun bir diğer nedeni ise, bu söylemin, yönetici ve işadamlanmızın içinde bulunduğu koşullardan doğan psikolojik ihtiyaçlan tatmin etmesidir. Devlet korumasınun kalktığı, rekabetçi, karmaşık ve dinamik koşullarla karşı karşıya bulunan Türk yönetici ve işadamları, bu belirsizliği kontrol etme ihtiyacı hissetmişlerdir. Bu ihtiyaç, zaten kültürel olarak belirsizlikten kaçınmanın yüksck olduğu Türkiye gibi bir toplumda (Hoftstede, 1984) kaçnılmaz görülmektedir. Guru söyleminin, belirsiz ve kaotik çevresel koşulları yorumlayan, gelişmeleri tahmin edilebilir kılan, somut, uygulanabilir (veya öyle görünen) ve kurtuluş vaadedici niteliği, bu ihtiyacı karşılamaktadır. Türk akademisyenlerinin genel ilkelerle bezenmiş, uygulaması koşullara bağlı ve somut çözümleri yöneticilere bırakan kuramsal reçetelerinden farklı olarak guru söylemi, işadamları ve yöneticilere "şunu şunu yaparsanız başarll olursunuz" demektedir. Bu ise, Türk iş çevrelerinin yıllarca özlemini duyduğu bir tarzdır.

Öte yandan, guru söyleminin temel değerleri ile, değişen Türk yöneticisinin değerleri arasındaki uyumluluk da, sözkonusu modaya katkıda bulunmuş olabilir. Capital ve RuyEBerndtson tarafından 135 üst düzey yönetici üzerinde yapılan bir araştırmanun sonuçlanna göre (Capital, 1998b: 158-162) tipik Türk yöneticisi, kolej mezunu, eğitimini yurtdışında tamamlamış, 38 yaşında ve haftada ortalama 52 saat çalışan, kariyer olanakların geliştirmeye odaklanmıs, bireyci bir kişilik taşımaktadır. Guru söylemi de, bireycilik ve liderlik gibi değerleri körükleycrek ve buna ilişkin teknikler sunarak bir yandan, yöneticilerimizin bu değerlerini okşamakta, diğer yandan da huzh kariyer yapmada işe yarayacak araçlarla donatmaktadır. Ayrıca, Clark ve Salaman'ın (Clark ve Salaman, 1998: 143) belirttiği gibi, gurular, karizmatik kişilikleri, insanları etkileme ve ikna etme yetenekleri ile, yöneticilerimizin arzuladığı bir rol modeli sunuyor olabilirler.

Clark ve Salaman'ın sunduğu yeni açılama biçimi de, Türkiye'deki guru modası olgusunu anlamada yararlı olabilir; buna göre, guruların çağdaş üst düzey yöneticiler için çizdiği kahraman, dönüştürücü lider kimliği, yöneticiler için çckici bir unsur olmakta, kendilerini bu kimlikle özdeşleştirme isteği, onları gurulara ilgi duyar hale getirmektedir. Guru söyleminin sunduğu bu kimlik ile, Türk işadamlanı ve yöneticilerinin tarihsel gelişim sürecinde edindiği güncel kimlik arasında bir benzerlik bulunmaktadır. Türk toplumsal yapısının 
gelişiminde, devletin merkezi role sahip olması, burjuvazinin az gelişmişliği, ticaret-imalat gibi toplumsal işlevlerin azınlıklara bırakılması ve yerli sermayenin devlete bağımlı olarak gelişmesi, geleneksel olarak, işadamlığı ve özel sektör yöneticiliği gibi mesleklere şüpheyle bakılmasına ve sivil-askeri bürokrasi karşısında daha az itibar edilmesine neden olmuştur (Heper, 1976: 485-500). Ancak yaşanan süreç içinde güçlenen bu kesim, 1980'lerdeki kendileri için olumlu koşulları da arkalarına alarak itibar kazanmı̧, örgütleri aracılığıyla (örn., TÜSIAD) ve bireysel çkışlarla (örn., Sakıp Sabanc, Ishak Alaton) ülke yönetimine alternatif çözümler üretir konuma gelmişlerdir. Bu, Türk işadamlan ve yöneticileri için geçmiştekinden farklı bir kimliktir; bağımsız, çözüm üreten, değişimden yana bir kimlik. Işte, guru söyleminin bu kesime sunduğu kahraman, dönüştürücü lider kimliği, tarihsel süreç içinde Türk işadamlan ve yöneticilerinin edinmeye çalıştığı kimliği destekler görünmektedir. Dolayısıyla, guru seminerleri de, bu kimliğin pekiştirildiği törenler olarak düşünülebilir.

Son olarak, yöneticilerin guru söylemine ve özellikle guru seminerlerine ilgi göstermesine bazı sosyopsikolojik etmenlerin katkıda bulunduğu söylenebilir. Abrahamson'ın (Abrahamson, 1996: 272) belirttiği gibi, yöneticilerimiz farklı, ancak aykırı görünmemek için bu modaya ilgi gösteriyor olabilir. Farklı görünerek bircyselliklcrini tatmin etmek, ancak bunu bir grupla birlikte yaparak kınanmaktan kaçınmak, riskli olmayan, prestij kazandırı̀ bir tavir gibi görünmektedir. Nitekim, moda olgusu, ona uyanlara, uymayanlara göre daha yüksck statü sağlayan bir olgudur. Dolayısıyla, bin dolarlara varan ücretler karşıllığında ve 60-100 kişiyi geçmeyen dar bir çevrenin katılabildiği (Capital, 1998a: 174) guru seminerlerine gitmek, guruyu dinleme niyetinin ötesinde, o prestijli kulübe ait olma niyetinden kaynaklanabilir. Ayrica, yöneticiler kendi aralarınđaki etkileşimle ("şu guruyu dinledin mi?" türünden), bu eğilimi körüklüyor olabilirler. Kolcktivist yönü ağır basan toplumsal karakterimiz, böylesi bir etkileşim için elverişli bir zemin oluşturmaktadır. Ayrıca, toplumca okuyarak değil de, dinleyerck öğrenmeye olan yatkınlığımız, yöneticilerimizin guru kitaplarını okumak ycrine guru seminerlerini izlemeye yönlendirmiş olabilir. Dolayısıyla, işitsel temclli bir toplum oluşumuz bu seminerlere olan ilgiye katkı sağlıyor olabilir.

\section{Türk Akademisyenlerinin Guru Söylemine Olası Tepkileri ve Alınacak Dersler}

Aralarında geçişmeler olmakla birlikte, gurular ve akademisyenler temel olarak, yönetim bilgisi alanında birbirine rakip olan gruplardır. Bazen birbirlerinin tarzlarını kullanmakla birlikte, yukarıda belirttiğimiz gibi, bilgiyi üretme, yayma ve ürettikleri bilginin niteliği açısından temel farklılıklar taşımaktadırlar. Bu farklılıklara dayanarak şöyle bir tez ileri sürülebilir; 
"akademisyenler genellikle kuramsal, gurular da genellikle uygulamaya dönük bilgiler ürettiklerinden, bunlar birbirine rakip değil birbirini tamamlayan gruplardır". Ancak, gerçek hayattaki koşullar bu tezi desteklememektedir. Yönetim gibi uygulamalı bir bilim dalında çalışan akademisyenler, uygulamaya katkıda bulunma zorunluluğu hissetmekte ve bu yönde çözümler geliştirmekte veya en azından uygulamaya yön verecek kuramsal çalışmalar yapmakta; gurular ise temelde reçete üretmekle birlikte, "kuram" geliştirme hevesi taşımaktadırlar. Bu nedenle hem işlevlerinin, hem de hitap ettikleri kitlenin çakışması (yöneticiler) nedeniyle, gurular ve akademisyenleri rakip gruplar olarak kabul edebiliriz.

Bu temel saptamayı yaptıktan sonra, Türkiye'de yaşanan guru söylemi modası karşısında akademisyenlerin sergilediği olası tepkileri incelemeye çalışalım. Türkiye'deki Yönetim yazınnndaki gelişmeler ve ulusal kongrelerdeki tartışmalardan edindiğimiz izlenimlere dayanarak, Türk akademisyenlerinin guru söylemine başlıca dört biçinde tepki gösterdiğini söyleyebiliriz; (1) balıklama atlamak, (2) kayıtsız kalmak, (3) reddetmek-küçümsemek ve (4) anlamak-ders çıkarmak.

Balıklama atlamak, gurular ne söylerse söylesin tartışmasız kabul eden, bu söylemi herhangi bir kriter (bilimscl ilkcler, etik ve insancll değerler, ulusal kültüre uyumluluk,... gibi) kullanmaksızın benimseyen grubun tepkisini ifade etmektedir. Yukarıda belirttiğimiz, Türk Yönetim yazınında guru söylemine karşı artan ilgi, bu grubun azımsanmayacak büyüklükte olduğunu göstermektedir. Bu tepkinin arkasında, akademik yaşamımızın genel karakteri olan, gelişmiş ülkelerdcki (özellikle ABD'de) moda yönetim bilgisini Türkiye'ye aktarma geleneği olabileceği gibi, Türkiye'de bu yönetim bilgisine duyulan talep karşısında bazı akademisyenlerin iştahının kabarması olabilir (çünkü, guru söylemi piyasada iyi para getirmektedir). Bu grup, bilinçli veya bilinçsiz olarak guru söyleminin adeta "fiili acentası" olarak çalışmaktadır. Hatta aralarında, "ulusal guru" olma hevesinde olanlar da bulunabilir.

Kayıtsız kalmak, guru söyleminin bir "moda" olduğunu düşünerek, "yarın bir gün gözden düşecek konular" üzerinde çalı̧̧mak istemeyen ve bu nedenle guru söylemine kayıtsız kalan akademisyenlerin tavrın temsil etmektedir. Bu grup, guru söılemini göz ucuyla izlemekte, şimdiye kadar bildiklerinden pek farklı bir şey söylenmediğini düşünerek, kendine güveni daha da artmıs bir biçimde rutin çalışmalarına devam etmektedir. Bu grup, fırtınanun dinmesini beklemcktedir.

Reddetmek-küçümsemek, guru söylemini bilimsel, kültürel, etik veya ideolojik kriterlere göre değerlendirerek "geçer" not vermeyen ve tepkilerini reddetme, hatta küçümscme biçiminde gösteren akademisyenlerimizin tepkilerine karşıllık gelmektedir. Akademisyenler arasında azınlıkta kalan ancak, 
en radikal grup olan bu grubun guru söylemini reddetme nedenleri farklılaşmaktadır. Bazıları, guru söylemini "zaten bilinen şeylerin makyajlanmış biçimi" olarak değerlendirmekte ve bu tepkilerini açlk açk dile getirerek kayıtsız kalanlardan farklılaşmaktadırlar. Bazıları, bu konuda yapılan araştırmalara ve kendi gözlemlerine dayanarak, guru reçetelerinin kendi içinde çelişkili olduğunu ve (iddia ettiğinin tersine) örgütleri çoğunlukla başarısızliğa götürdüğünü ileri sürmektedirler. Belirli bir kesim, guru söyleminin yeteri kadar "bilimsel" nitelikli olmadığın, söylemdeki reçetelerin birer "teori" olarak değerlendirilemeyeceğini, bunun üzerine "bilim" yaplamayacağın ve bu söylemin gerisinde "bilimsel" değil "ticari" kaygıların yattı̆ın ileri sürmektedir. Bazı akademisyenler ise, guru söyleminin dayandığı neo-liberal ideolojinin temel değerlerini benimsemedikleri için bu söylemi toptan reddetmektedir. Son olarak, belirli bir kesim ise, guru reçetelerinin ulusal kültüre uyumu konusunda şüpheleri olduğundan, sözkonusu söylemi reddetmektedir. Tahmin edilebileceği gibi, balıklama atlayanlarla reddedenler arasında, bilimsel toplantılarda yoğun tartışmalar yaşanmaktadır.

Son olarak, tepkisini, anlamak ve ders çıkartmak biçiminde koyan bir kesimden sözedilebilir. Guru söylemini ve onun ötesinde guru modasın anlamaya, ulaştığı sonuçları ilgili gruplarla paylaşarak, bir öğrenme sürecini başlatmaya çalışan bu kesimin temcl önceliği, guru söyleminin içeriği değil, guruların ve guru söyleminin "neden moda olduğudur". Guru modasını "sosyal bir vakıa" ve guruları da, ürettikleri bilgi ne derece geçersiz, yüzeysel ve tartışmalı olsa da, temelde bir "fikir üreticisi" olarak görürler. Bu kesimin, guru söyleminin içeriğine eleştirel bir bakışla bakmadığı söylenemez, ancak temel önceliği söylemin içeriği değil, nasıl ve neden moda olduğudur. Yönetim alanunda küçümsenmeyecek bir gelişme olarak guru söyleminin moda olma sürecini, adeta bir sosyolog vera sosyalpsikolog gibi inceleyerek, bu modanin nedenlerini ortaya koymaya çalışırlar ve bu nedenlerden yola çıkarak, yönetim bilgisi alanındaki taraflar için çeşitli dersler çıkarırlar.

Aslında bu yaklaşım Abrahamson'ın (Abrahamson, 1996) önerdiği ve bu çalışmada da benimsenen yaklaşımdır. Abrahamson'a (ibid., 279-280) göre, yönetim modası, "moda" sözcüğünün yarattığı çağrışıma rağmen, gelip geçici bir olgu değil, uıgulamayı derinden etkileyen ve popülaritesini kısmen kaybetse bile, derin izler bırakabilen bir olgudur. Bu nedenle, yönetim bilgisi alanının üreticilerinden biri olan akademisyenlerin bu olguı kayıtsız kalmamaları gerckmektedir. Yönetim modası oluşturma sürecini anlamanun ötesinde, akademisyenler bu anlayıştan çıkaracakları derslerle bu sürece müdahale etmelidirler. Bu müdahale, guruların kullandığ yöntemleri kullanan birer "akademik guru" olmaktan ziyade, bu alanda geçerli olmasi gereken temel normları oluşturmak ve ilgili taraflarla (öğrenciler, yöneticiler, akademisyenler) bu normları paylaşmak sonucunu doğurmalıdır. 
Çalışmada son olarak, açıklayıcı çerçeveden çıkardığımız dersler doğrultusunda akademisyenlerimizin bu sürece müdahale ederken neler yapabileceklerini sıralamaya çalışacağız.

1. Akademisyenimiz rolünü yeniden tanımlamalıdır: Yönetim alanunda çalş̧an bir akademisyenin rolü, sadece öğrenci yetiştirmek ve kapalı kapılar ardında araştırma yapmak değil, uygulamalı bir disiplinde çalışmasının gereği olarak, uygulamaya kuramsal ve pratik çözümler sunmak olmalıdır. Ancak, bir akademisyen bu çözümleri sunarken, sadece "yönetenleri" (yöneticiler, işadamları, sermayedarlar) mutlu kılan reçeteler ya da yönetilenleri de mutlu "ediyormuş gibi" görünen ancak, temelde yönetenlerin çıkarlarını tatmin eden reçeteler (örneğin "Empowerment") sunmak olmamalıdır. Ayrıca bu tavır, ayrıntılı ve kapsamlı ampirik araştırmalara dayanmaksızın, yüzeysel ve ucuz reçeteler üretmek biçiminde de olmamalıdır. Bir akademisyene düşen görev, yönetenlerin ve yönetilenlerin mutluluğunu ve bunun ötesinde de, toplumun genel mutluluğunu optimum düzeye çıkaran, ayrıntılı bilimsel araştırmalara dayanan çözümler sunmaktır. Kısacası, bir akademisyen, konumu gereği, etik ve bilimsel değerleri izlemelidir. Bu değerleri, bir yandan çözümlerinde yansıtmalı, diğer yandan da çeşitli iletişim mekanizmaları ile bu değerleri Yönetim alanının ilgili tarafları ile (yöneticiler, sendikalar, diğer akademisyenler, danı̧̧manlık kuruluşları...vb.) paylaşmalıdır. Bu paylaşım sürecinde akademisyen, guru söyleminden doğan reçetelerin bu değerlere uyumsuzluğunu açık açık dile getirmelidir. Bir akademisyen, ancak böylesi bir aktif rol üslenerek, moda sürecine anlamlı bir müdahalede bulunabilir.

2. Akademisyenimiz, $A B D^{\prime}$ den bilgi aktarmaktan vazgeçip özgün çözümler üretmelidir: Yönetim olgusu kültürler arasında ortak yönler taşımakla birlikte, temelde içinde bulunduğu kültüre bağımlı bir olgudur. Dolayısıyla, kuramsal ve uigulamaya dönük geçerli bilgi üretmek için bir akademisyenin mutlaka ve mutlaka içinde bulunduğu kültürün, yönetim olgusuna yansımaların araştırması ve özümsemesi gerckmektedir. Oysa ki, Türkiye'de akademisyenler "alana" inmekten hep kaçınmışlar, yönetim olgusunun tamamen evrensel olduğu yanılgısıyla, gelişmiş ülkelerde geçerli olan Yönetim bilgisini sürekli Türkiye'ye ithal etmişlerdir. Dolayısıyla akademisyenler genellikle, bilginin üretildiği kültürün gündeminde olan yönetsel sorunlara yönelik ve o kültürün özelliklerine uygun çözümleri, Türkiye'nin gündemindeki yönetsel sorunları ve kültürel özellikleri dikkate almaksızın taşımışlardır. Böylesi bir eylemin sonucunda da, bazen "çözüm" yerine, bilginin üretildiği ülkede yaşanan bir "sorun" ithal edilmiştir (Türkiye'de böylesi bir sorun yaşanmadığı halde). Örneğin, ABD'de Taylorizme alternatif olarak üretilen Insan Ilişkileri yaklaşımı, sanki Türkiye'de Batı'daki anlamda Taylorizm uygulanyormuş gibi, bir çözüm olarak sunulmuştur Bazen de, kültürel farklılıklardan ötürü Türkiye'de uygulanması çok gụ̧̈ olan çözümler ithal 
edilmiştir; örneğin, Amaçlara Göre Yönetim (Management by Objectives). Sonuç olarak, uygulayıcılar gözünde akademisyen genellikle "kulağa ho̧ gelen, ancak geçerli şeyler söylemeyen" kişiler olarak kalmıştır.

Burada, 6. İşletmecilik Kongresinin TKY konulu kapanış panelinde, yöneticiler ile akademisyenler arasında geçen diyaloğa ilişkin izlenimlerimizi aktarmak, özellikle iki grup arasındaki anlayıs ve konum farklılığın açıklığa kavuşturmak açsından yararlı olacaktır. Panel konuşmacıları, Türkiye ve Avrupa Kalite ödülleri almış şirketlerin üst düzey yöneticilerinden, dinleyiciler ise büyük ölçüde Işletmecilik alanında çalışan akademisyenlerden oluşmaktaydı. Yöneticiler TKY felsefesini ve uygulamaların anlattıkça, akademisyenlerden "biz bunları zaten biliyoruz" tepkileri yükseldi. Evet, akademisyenlerimiz, TKY'nin temel unsurları olan "verilerle yönetim", "içmüşteri memnuniyeti/katılım", "müşteriye odaklılık" gibi konuları, sırasıyla, Taylor'ın Bilimsel Yönetimi, Drucker, McGregor'in Insan liş̧kileri ve Lewitt'in "müşteriye dönüklük" anlayışı çerçevesinde yıllardır Türkiye'ye aktarmışlardı. Ancak, Başkent Üniversitesinden Sclami Sargutun belirttiği gibi "TKY'nin şimdiye kadar söylenenlerin, genellikle mühendis kökenli olan yöneticilerimizin anlayabileceği ve uygulayabileceği somutluğa indirgenmiş bir sentezi" olduğunun farkında değildik. Dolayısıyla, akademisyenlerimizin kopuk kopuk ve belirgin olarak neyin nasıl yaplacağını değil de "genel bazı ilkeleri" veren aktarma söylemleri, yöneticiler nezdinde hedefini bulmamıştır. Doğal olarak, "Yöneticiler yıllardır akademisyenlerin söylediklerine kulak asmadılar da, neden son ylllarda yönetim bilgisine bu denli ilgi duyuyorlar?" sorusunun cevabı ise, yukarıda belirttiğimiz makroekonomik koşullardaki değişimin itici gücünde yatmaktadır; kısaca, yöneticileriniz "zorda kalnışlardır". Ama zorda kaldıklarında da, Türk akademisyenlere değil uluslararası danışmanlık şirketlerine ve gurulara başvurmuşlardır. Bu eğilim, "aktarıcıdan" ziyade "asıl kaynağına" gitmek gibi, yöncticilerimiz açısından akılcı bir davranış ve akademisyenlerimizin de hiç gücenmemesi gercken bir olgudur.

Sonuç olarak, akademisyenlerimiz uygulamaya katkıda bulunmak ve inandırıcı olmak istiyorlarsa, bir yandan Yönetime ilişkin uluslararası gelişmeleri izlerken, diğer yandan da Türkiye'de yaşanan yönetsel sorunları ve kültüre özgü özcllikleri dikkate alarak özgün çözümler üretmelidir. Akademisyenlerimize düşen bir diğer görev ise, özellikic yöneticilerimizin ve çoğu akademisyenin paylaştığı "ABD'de uygulanıyorsa Türkiye'de de uygulanır" yanılgısın, çeşitli iletişin biçimleriyle gidermeye çalışmasıdır. Bunun için bir yandan özgün çözümler üretirken, diğer yandan da "evrensel" geçerliliği varmış gibi sunulan guru reçetelerinin geçersizliğini ilgili taraflarla paylaşmalıdırlar. 


\section{Sonuç}

Uzun yllar Insan tlişkileri söyleminin egemenliği altunda tekdüze bir görünüm sergileyen ve bu niteliği ile uluslararası yazındaki yönetim modası sürecinden farklılaşan Türk Yönetim yazını, 1980'lerde uluslararası yazınla çakışarak, bu yazında moda olan guru söylemini gittikçe daha fazla benimser hale gelmiştir. Öte yandan, tarihinde belki ilk kez, uygulayıc çevreler, uluslararası alanda moda olan yönetim bilgisine (guru söylemi) bu denli yüksek düzeyde ilgi göstermişlerdir. Uluslararası moda pazarının dışında olan ve bu pazardan bilgi ithal eden Türk Yönetim alanındaki bu gelişmenin itici gücü, ekonomik yapıda 1980 'lerde yaşanan değişimlerdir. Kapitalist dünya düzeniyle bütünleşme çabası sonucunda, ulusal ve uluslararası pazarlardaki yeni koşullara uyum sağlama zorunluluğu, Türk şirketlerini, o ylllarda uluslararası Yönetim yazınunda moda olan yönetim tekniklerine yönel tmiştir. Giderek yaygınlaşan bu talebe karşılık, uluslararası yazından moda yönctim teknikleri ithal eden danışmanlık, eğitim ve yayın şirketleri kurulmus ve Türk yönetim modası pazarının kurumsal yapısı oluşmuştur. Bu kuruluşlar, guru söylemi ile birlikte, onun bir kurumu olan guru seminerlerini ithal etmişlerdir. Guru söylemine ve gurulara duyulan ilgi, bircy düzeyinde şeşitli kişiliksel ve sosyopsikolojik etmenlerle de pekişmiştir. Bu etmenler arasında, gelişmiş Batı ülkelerini model alma geleneği, guru söyleminin içerik ve biçim olarak Türk yöneticilerinin ihtiyaçlan ve değerleri ile uyumluluk göstermesi, yöneticilerin ve işadamlarının yeni kimliklerini pekiştirmeyc hizmet etmesi, modaya ayak uydurarak farklı olma ve prestij kazanma güdülerini tatmin etmesi sayllabilir. Bu nitelikleriyle, Türkiye'de oluşan yönetim modası pazarı, Abrahamson'ın çizdiği "rasyonel" sürecin özelliklerini yansıtmakla birlikte, azgelişmişlik sendromundan, prestij kazanmaktan, "modernmiş gibi" görünmekten ve kimlik edinme uğraşından kaynaklanan, temelde irrasyonel nitelikler taşımaktadır.

Yönetim alanının geleneksel bilgi üreticileri olan akademisyenlerimizin, yaşanan guru modası karşısındaki tepkileri, balıklama atlamak, kayıtsız kalmak, reddetmek ve anlamaya çalışmak biçiminde farklllaşmaktadır. Eğer akademisyenlerimiz uygulamaya katkı sağlamak istiyorlarsa, bu modanın nedenlerini anlamaya çalışarak, moda oluşturma sürecine müdahale etmek için çeşitli dersler çıkarmalıdır. Yönetim alanında çalışan akademisyenlerimiz, etik ve bilimsel değerleri temel alarak, Türk Yönetim alanına ilişkin sorunlara yönelik ve kültürel özelliklerimize uyumlu çözümler üretmeli ve bu süreci Yönetim alanının ilgili tarafları ile paılaşmalıdır.

\section{Kaynakça}

Abrahamson, E. (1991) "Management Fads and Fashions: The Diffusion and Rejection of Innovations," Academy of Management Review, 16 (3) $586-612$. 
Abrahamson, E. (1996) "Management Fashion," Academy of Management Reoiew, 21(1) 254-285.

Abrahamson, E. (1997) "The Emergence and Prevalence of Employee Management Rhetorics: The Effects of Long Waves, Labor Unions, and Turnover, 1875-1992," Academy of Management Joumal, 40(3) 491-533.

Alvarez, J.I. (1996) "The International Popularization of Entrepreneurial Ideas," The Politics of Management Knowledge (Der) S.R.Clegg ve C.Palmer, London:Sage, 80-98.

Barley, S.K. ve G.Kunda (1992) "Design and Devotion: Surges in Rational and Normative Ideologies of Control in Managerial Discourse," Administrative Science Quarterly, (37) 363-399.

Capital (1997) "Hangi Danışman," (1) 130-131.

Capital (1998a) "Guru Yağmuru," (6) 172-175.

Capital (1998b) "Türkiyènin Yeni Yönetici Profili," (7) 158-162.

Clark, T. ve G.Salaman (1996a) "The Management Curu as a Organizational Witch-Doctor," Organization, 3 (1) 85-107.

Clark, T. ve C. Salaman (1996b) "Telling Tales: Management Consultancy as the Art of Story Telling," Metaphor and Organizations. D.Crant ve C.Oswick (Der), Sage: London, 166-184.

Clark, T. ve G. Salaman (1998) "Telling Tales: Management Gurus' Narratives and the Construction of Managerial Identity," Journal of Management Studies, 35(2) 137-161.

Conrad, C. (1985) "Review of $A$ Passion for Excellence: The Leadership Difference," Administrative Science Quarterly, 30, 426-429.

Freeman, F.H. (1985) "Books that Mean Business: The Management Best Seller," Academy of Management Review, 10, 345-350.

Furman, B. ve Y. Koralp (1997) “1972-1996 Yılları Arasında Türk Akademik Yazınında Yer Alan Yönetim Ideolojilerinin Değerlendirilmesi," 5. Ulusal Yönetim ve Organizasyon Kongresinde Sunulan Bildiri, Ankara.

Grint, K. (1994) "Reengineering History: Social Resonances and Business Process Reengineering," Organization, 1 (1) 179-201.

Heper, M. (1976) "The Recalcitrance of the Turkish Public Bureaucracy to Bourgeois Politics," The Middle East Jourmal, 30(4) 485-500.

Hofstede, G. (1984) Culture's Consequences (Abridged Edition) London: Sage.

Iluczynski, A. (1993) Management Gurus: What Makes Them and How to Become One. London Routledge.

Human Resources (1997a) "Yönetim Danışmanlanı Derneği," 1(1) 24-27.

Human Resources (1997b) "Celeceğin Is Insanı," 1(5) 29-35.

Micklethwait, J. ve A. Wooldridge (1996) The Witch Doctors: Making Sense of the Management Gurus. New York Times Books.

Özen, S. (1995) “Kamu Yönetimi Yazınımız ve Örgütler-Yönetim Calısma Alanı: Tehlikeli llişkiler,” Kamu Yönetimi Disiplini Sempoztumu Bildirileri I. Ankara: TODAYE, 71-96.

Özen, S. (1996) Bürokratik Kültür 1: Yönetsel Değerlerin Toplumsal Temelleri. Ankara: TODAIE.

Ramsay, H. (1996) “Managing Sceptically: A Critique of Organizational Fashion,” The Politics of Management Knowledge (Der) S.R.Clegg ve G.lPalmer, L.undon:Sage, 155-172.

Sandkull, B. (1996) "Lean Production: The Myth which Changes the World," The Politics of Management Knowledge (Der) S.R.Clegg ve C.Palmer, London:Sage, 69-79.

Shapiro, E. (1997) "Managing in the Age of Gurus," Harvard Business Review, March-April, 142-147. 
Şükrü 0̈zen • Türkiye'deki Guru Soylemi Modasının Nedenleri • 121

Üsdiken, B. ve Y. Pasadeos (1993) "Türkiye'de Örgütler ve Yönetim Yazını," Amme ldaresi Dergisi, 26(2) 73-93.

Üsdiken, B., N. Selekler ve D. Çctin (1998) "Türkiyc'de Yönetim Yazınına Fgemen Anlayışın Oluşumu: Sevk ve ldare Dergisi Üzerine Bir Inceleme," Amme Idaresi Dergisi, 31(1) 57-88. 